\title{
逆圧力勾配乱流境界層の数值予測*
}

\author{
野村＼cjkstart駿*1, 橋 詰＼cjkstart諒*2, 島信 行*3

\section{Prediction of Turbulent Boundary Layers in Adverse Pressure Gradients}

Takashi NOMURA*4, Ryo HASHIZUME and Nobuyuki SHIMA

*4 Department of Mechanical Engineering, Shizuoka University,
3-5-1 Johoku, Hamamatsu-shi, Shizuoka, 432-8561 Japan

\begin{abstract}
A second-moment closure proposed by Shima and Kobayashi (2007) is applied to turbulent boundary layers in adverse pressure gradients. The computation adopts a very simple 'standard' model for the $\varepsilon$ transport equation. In spite of the simple scale-determining equation, the closure reproduces a case that is often used for testing turbulence models, i. e. the Samuel-Joubert flow in which a standard log law region exists. The model is also tested in equilibrium boundary layers of a recent DNS, in which the velocity profile in the log law region shifts downward from the standard law and the slope in that region becomes higher than that for the zero pressure gradient flow. The present model gives reasonable predictions for mild and moderate pressure gradient cases, but fails to capture a mean velocity profile for a strong gradient case. The Launder-Sharma $k^{-} \varepsilon$ model is also tested in these cases, and the performance is discussed.
\end{abstract}

Key Words : Turbulent Flow, Boundary Layer, Computational Fluid Dynamics, Turbulence Model, Second-Moment Closure, Adverse Pressure Gradient

\section{1. 緒言}

逆圧力勾配のもとで発達する乱流境界層を精度良く 予測することは基本的に重要な課題である． $k$ - $\varepsilon$ モデ ルや応力方程式モデルにとって，逆圧力勾配境界層は 予測の難しい流れであることは古くから認識されてい た (Kline $ら^{(1)}$, Patel $ら^{(2)(3)}$ ). モデル検証はしばしば, Samuel-Joubert ${ }^{(4)}$ の実験を対象として行われたが，多 くのモデルがその低い壁面摩擦を再現できなかった. 最近, Viti ら ${ }^{(5)}$ は 5 種のモデルによってこの流れを計算 し，良好な予測が得られることを示している．用いら れたモデルのうち三つは応力方程式モデル (LaunderShima ${ }^{(6)}$, Jakirlić-Hanjalicic ${ }^{(7)}$, Manceau-Hanjalić( $\left.{ }^{(8)}\right)$ であ る.この好予測が何に起因するのか深必ずしも明らか ではないが，主として，乱れエネルギーの散逸率 $\varepsilon$ の 輸送方程式一の付加項の導入あるいはモデル係数の関 数化によっているものと思われる.

広い適用性を目指寸乱流モデルにとって，逆圧力勾

* 原稿受付 2009 年 5 月 29 日。

*1 准員, 静岡大学大学院工学研究科機械工学専攻 (画 432-8561 浜松市中区城北 3-5-1).

*2 アステラス富山(株) (—930-0809 富山市興人町 2-178).

*3 正員, 静岡大学工学部機械工学科(必 432-8561 浜松市中区 城北 3-5-1).

E-mail : f0930049@ipc.shizuoka.ac.jp
配境界層における性能検証は必須である、本研究で は，Shima-Kobayashi ${ }^{(9)}$ が提案した応力方程式モデル によって逆圧力勾配境界層の数值予測を行う．予測の 対象は，上で挙げた Samuel-Joubert の実験およびごく 最近の Lee-Sung ${ }^{(10)}$ D DNSである. 後者に対しては, 広く用いられている低レイノルズ数型 $k-\varepsilon$ モデルであ る Launder-Sharma ${ }^{(11)}$ モデルによる予測も行う.

\section{2. 乱 流モ テル}

Shima-Kobayashi ${ }^{(9)}$ が提案したモデルを要約する. 非圧縮の流れにおいて，レイノルズ応力の厳密な輸 送方程式は次のように書ける。

$$
\begin{gathered}
\frac{D}{\overline{D t} \overline{u_{i} u_{j}}}=P_{i j}-\varepsilon_{i j}+\Pi_{i j}+T_{i j}+V_{i j} \\
P_{i j}=-\left(\overline{u_{j} u_{k}} \frac{\partial U_{i}}{\partial x_{k}}+\overline{u_{i} u_{k}} \frac{\partial U_{j}}{\partial x_{k}}\right) \\
\varepsilon_{i j}=2 v \frac{\partial \frac{\partial u_{i}}{\partial x_{k}} \frac{\partial u_{j}}{\partial x_{k}}}{\Pi_{i j}}=-\frac{1}{\rho} \overline{\left(u_{i} \frac{\partial p}{\partial x_{j}}+u_{j} \frac{\partial p}{\partial x_{i}}\right)} \\
T_{i j}=-\frac{\partial}{\partial x_{k}} \overline{u_{i} u_{j} u_{k}} \\
V_{i j}=v \frac{\partial^{2}}{\partial x_{k} \partial x_{k}} \overline{u_{i} u_{j}}
\end{gathered}
$$


ここで, $U_{i}, u_{i}$ はそれぞれ速度の平均分, 変動分, $p$ は圧力の変動分, $v$ 慟粘度, $\rho$ は密度であり, バー は平均を示している. 式(2) (6) で定義された各項は, 順に, 生成, 散逸, 速度 - 圧力勾配相関, 乱流拡散, 粘性应散である。

生成 $P_{i j}$ と粘性拡散 $V_{i j}$ はモデル化の必要がない. 乱流拡散 $T_{i j}$ には次の Daly-Harlow ${ }^{(12)}$ モデルが採用さ れる。

$$
T_{i j}=\frac{\partial}{\partial x_{k}}\left(C_{S} \frac{k}{\varepsilon} \overline{u_{k} u_{l}} \frac{\partial \overline{u_{i} u_{j}}}{\partial x_{l}}\right)
$$

ここで， $k$ は乱れエネルギー， $\varepsilon$ はその散逸率である.

散逸 $\varepsilon_{i j}$ と速度・圧力勾配相関 $\Pi_{i j}$ のモデリングに あたっては，壁面効果を代表するべクトル $N_{i}$ が次の 棈円型方程式の解として導入される.

$$
L^{2} \frac{\partial^{2} N_{i}}{\partial x_{k} \partial x_{k}}-N_{i}=0
$$

ここで， $L$ は次式で定義される乱れの長さスケールで ある。

$$
L=C_{L} \max \left[\frac{k^{3 / 2}}{\varepsilon}, C_{\eta}\left(\frac{\nu^{3}}{\varepsilon}\right)^{1 / 4}\right]
$$

方程式 (8) の壁面境界条件は

$$
N_{i}=n_{i}
$$

である.ここで, $n_{i}$ は壁面単位法線べクトルである. したがって， $N_{i}$ は壁で $n_{i}$ に一致し，壁から遠ざかる につれてゼロに近づいていくべクトルである.このべ クトル $N_{i}$ 老用いて, 散逸と速度・圧力勾配相関の和 が次のようにモデル化される.

$$
\begin{aligned}
& -\varepsilon_{i j}+\Pi_{i j}=-\frac{\varepsilon}{k} \overline{\bar{u}_{i} u_{j}}+(1-N) \phi_{i j}^{*}+\phi_{W i j} \\
& \phi_{i j}^{*}=-\left(C_{1}-1\right) \frac{\tilde{\varepsilon}}{k}\left(\overline{u_{i} u_{j}}-\frac{2}{3} k \delta_{i j}\right)-C_{2}\left(P_{i j}-\frac{2}{3} P \delta_{i j}\right) \\
& -C_{3}\left(D_{i j}-\frac{2}{3} P \delta_{i j}\right)-C_{4} k\left(\frac{\partial U_{i}}{\partial x_{j}}+\frac{\partial U_{j}}{\partial x_{i}}\right) \\
& \phi_{W i j}=-C_{W} \frac{\varepsilon}{k}\left(\overline{u_{i} u_{k}} N_{j} N_{k}+\overline{u_{j} u_{k}} N_{i} N_{k}-\frac{2}{3} \overline{u_{l} u_{k}} N_{l} N_{k} \delta_{i j}\right) \\
& \text { ここで } \\
& \begin{array}{c}
\tilde{\varepsilon}=\varepsilon-2 v\left(\frac{\partial k^{1 / 2}}{\partial x_{l}}\right)^{2} \\
D_{i j}=-\left(\overline{u_{j} u_{k}} \frac{\partial U_{k}}{\partial x_{i}}+\overline{u_{i} u_{k}} \frac{\partial U_{k}}{\partial x_{j}}\right)
\end{array}
\end{aligned}
$$

モデル， $C_{2} \sim C_{4}$ ラピッドモデルの和に帰着する. 壁 に近づくと, 式(11) 右辺において, 第 1 項と第 3 項が 支配的になる。 $(1-N) \phi_{i j}^{*}$ は自由乱流における再分配 プロセスの壁面の存在による修正， $\phi_{W i j}$ は壁乱流にの み存在する再分配プロセスを表している;

$\varepsilon$ 輸送方程式としては次式が採用されている.

$$
\frac{D \varepsilon}{D t}=C_{\varepsilon 1} \frac{\varepsilon}{k} P-C_{\varepsilon 2} \frac{\varepsilon \widetilde{\varepsilon}}{k}+\frac{\partial}{\partial x_{k}}\left(C_{\varepsilon} \frac{k}{\varepsilon} \overline{u_{k} u_{l}} \frac{\partial \varepsilon}{\partial x_{l}}+v \frac{\partial \varepsilon}{\partial x_{k}}\right)_{(16)}
$$

これは最もシンプルな標準形である.

モデル定数の值は以下のとおりである.

$$
\begin{gathered}
C_{S}=0.2 \\
C_{L}=0.31, C_{\eta}=60 \\
C_{1}=2.5, C_{2}=0.45, C_{3}=0.23, C_{4}=0.22 . \\
C_{W}=\frac{15}{4} \\
C_{\varepsilon 1}=1.44, C_{\varepsilon 2}=1.92, C_{\varepsilon}=0.15
\end{gathered}
$$

このモデルの特徵は, 境界条件 (10)のもとでの方程 式 (8) の解として一つのベクトルを導入し，それを用 いて，再分配項として扱われる速度・圧力勾配相関と 散逸の和を式(11)のようにモデル化している点にあ る. その他については，既存の代表的でシンプルなモ デルが採用されている．また，モデル係数は関数では なく，すべて定数として与えられている.

\section{3. 予測対象と数值解法}

3.1 Samuel-Joubert ${ }^{(4)}$ の実験 図 1 に SamuelJoubert の実験における境界層外縁での圧力係数 $C_{p}$ の 流れ方向変化を示す. $x$ は流れ方向座標である. 図に 見るように，単に圧力が増大寸るだけではなく，中流 域までは圧力勾配も増大する流れである。

圧力勾配パラメータ $\boldsymbol{\beta}=\left(\boldsymbol{\delta}^{*} / \tau_{w}\right) d P / d x$ は下流に向 かって増大する $\left(\delta^{*}\right.$ は排除厚さ， $\tau_{w}$ は壁面せん断応 力). 後に平均速度分布を検討寸る二つの位置 $x=2.87$, $3.40 m$ において， $\beta$ の值はそれぞれ 2.90, 7.72 である. また，それらの位置における，運動量厚さに基づくレ イノルズ数 $\operatorname{Re}_{\theta}$ はそれぞれ 12600,18400 である.Viti ら ${ }^{(5)}$ はこの流れの圧力勾配の強さを中程度 (moderate) と表現している.

計算においては，上流に圧力勾配ぜロの領域を設 け，流入境界には乱れ強さ $1 \%$ の一様流を与える. バ イパス遷移を起こした境界層の平均速度分布が, 実験 の最上流位置におけるデータと一致するように計算と 実験の流れ方向位置を対応させる．図 2 にその位置 $x=0.855 \mathrm{~m}$ における平均速度分布を示寸. $y$ は壁から 


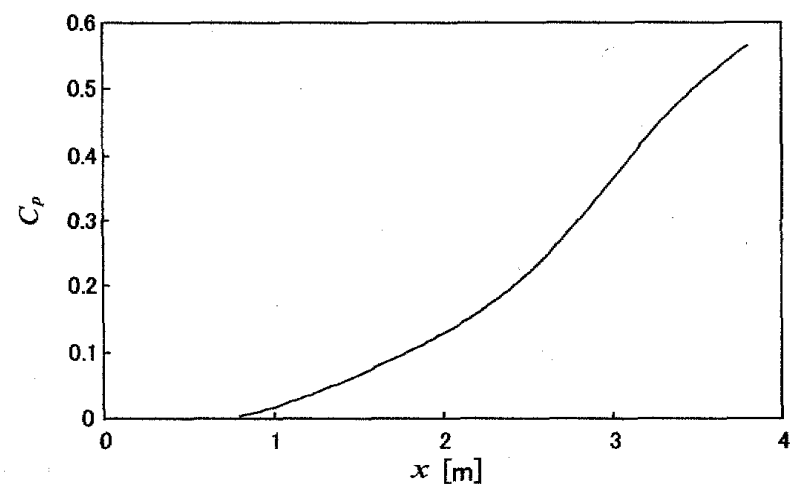

Fig. 1 Pressure coefficient (Samuel-Joubert flow)

の距離, $U$ は平均速度の $x$ 方向成分, $U_{e}$ は主流速で ある．計算で得た分布が実験データとほぼ一致してい ることが分かる.

流出境界条件は $x$ 方向の勾配ゼ口，壁面境界条件は すべりなしである，外縁境界条件として，圧力には図 1 の值を与え，その他についてはy 方向勾配ゼロと する.

有限体積法によって，方程式系を離散化した，対流 項の離散化スキームは，平均流では QUICK ${ }^{(13)}$ ，乱れ の方程式では 2 次線形法と 2 次上流法を組み合わせ たTVD ${ }^{(14)}$ である。圧力解法には SIMPLE ${ }^{(15)}$ を用いた。 $130 \times 70$ および $260 \times 140$ の不等間隔格子を用いて計 算を行い，結果に格子依存性のないことが確認されて いる.

3.2 Lee-Sung ${ }^{(10)}$ の DNS 主流速度が次式によっ て与えられ，十分下流に至るといわゆる平衡境界層が 得られる流れである。

$$
U_{e}(x)= \begin{cases}U_{0} & \text { for } x<0 \\ U_{0}\left(1-\frac{x}{x_{0}}\right)^{m} & \text { for } x>0\end{cases}
$$

3 種の $\mathrm{m}$ の值 $-0.075,-0.15,-0.20$ に対して DNS が行われている。平衡状態において $\left(\beta, R e_{\theta}\right)$ の值は それぞれのケースに対して $(0.25,850 \sim 1300)$ ，(0.73， $1000 \sim 1300),(1.68,1200 \sim 1400)$ である. Lee-Sung は, これらをそれぞれ弱い，中程度，強い逆压力勾配であ るとしている，図3にその主流速度変化を示す， $\theta_{i n}$ は 入口における運動量厚さである。本計算ではべルヌー イの式によって得た圧力変化を外縁で与えている．計 算結果の主流速が式 (22) とほぼ一致することは確か められている.

DNS において流入位置での流れは $\operatorname{Re}_{\theta}$ が 300 の平

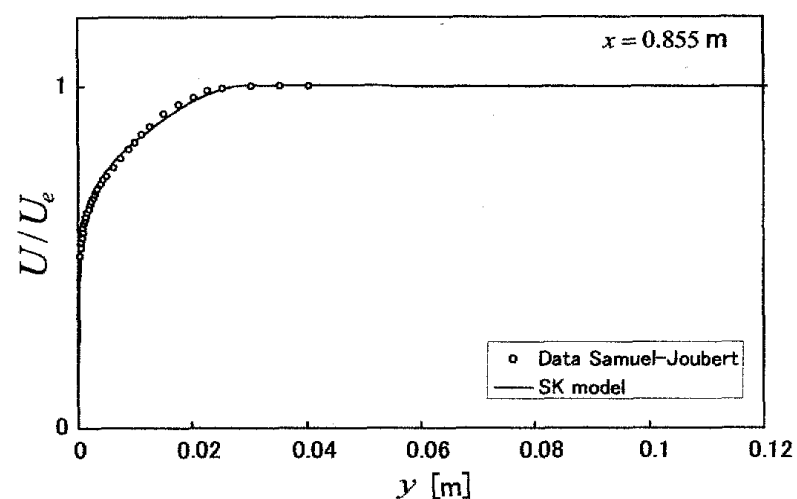

Fig. 2 Mean velocity profile at the inlet (SamuelJoubert flow)

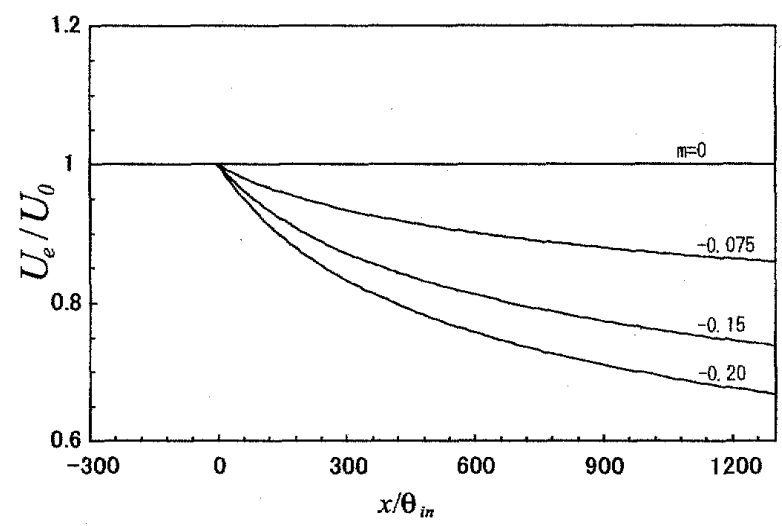

Fig. 3 Free-stream velocity (Lee-Sung flow)

板境界層である. 本計算では Spalart ${ }^{(16)}$ の DNS から得 た $R_{\theta}=300$ の境界層の諸分布を与える。だし， $\varepsilon$ と $N_{2}$ (ベクトル $N_{i}$ の $y$ 方向成分)については，諸量の $x$ 方向勾配をぜロとした方程式を解いて与えた，その 他の境界条件は Samuel-Joubert の場合と同じである.

離散化法，圧力解法は前述と同じである，格子につ いても，やはり $130 \times 70$ および $260 \times 140 の 2$ 種を用 いて計算を行い，結果に差がないことを確認した。

\section{4. 結果と考察}

4.1 Samuel-Joubert ${ }^{(4)} の$ 実験 以下では ShimaKobayashi のモデルを SK モデルと呼ぶ.

図 4 に壁面摩擦係数 $C_{f}$ の流孔力向変化を示す.ここ での摩摖係数は，圧力勾配がゼ口である上流域の主流 速を用いて定義されている，逆圧力勾配によって $C_{f}$ が 流れ方向に急速に低下していくことが，モデルによっ てよく捉えられている，最下流における不自然な変化 は勾配ゼロとした境界条件によっている。 


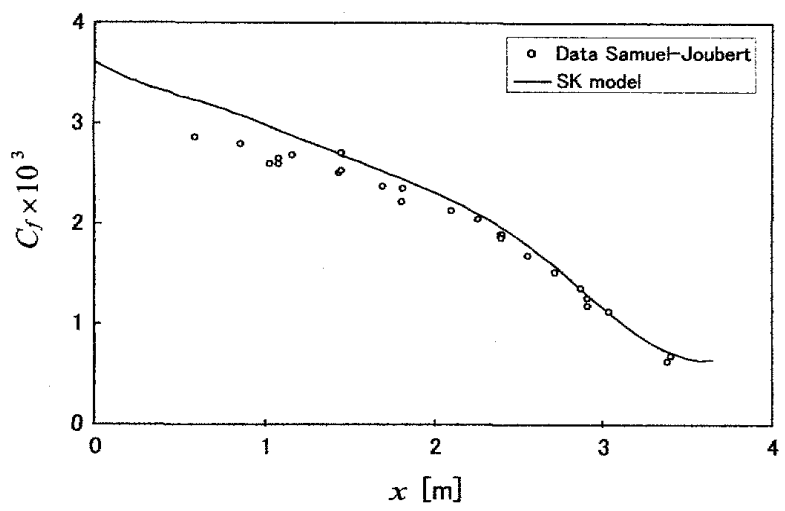

Fig. 4 Skin friction coefficient (Samuel- Joubert flow)

図 5,6に二つの位置に打ける平均速度分布を示す. 図6において, $U^{+}=U / U_{\tau}, y^{+}=U_{\tau} y / \nu, U_{\tau}$ は摩擦速 度である．図には，標準的な対数速度分布として，力 ルマン定数 0.418 ，切片定数 5.5 とした分布を示した. ここで,「標準的な」(あるいは以下で，「通常の」) 分 布とは，ゼロ圧力勾配でレイノルズ数が十分高い平板 境界層における分布を指している０.418, 5.5 という 数值は, Patel $ら^{(2)(3)}$ が多数の乱流モデルの性能評価定 行った際に用いた值を採用したものである。

モデルによる $\left(\beta, R e_{\theta}\right)$ の計算值は $x=2.87,3.40 m$ においてそれぞれ $(3.21,14100)$ ，(7.68, 19800) であり， 先に触れた実験值と比較すると $10 \%$ 程度の相違がある. 逆压力勾配境界層の特徽の一つは外層における大き 以伴流成分である，モデルはそれをよく再現している. 図に見るようにこの実験においては通常の対数則に したがう領域が存在する，そして，モデルはそれを忠 実にとらえている.

逆圧力勾配境界層における対数則については, 徒来, 議論のあるところである. Nagano $ら^{(17)}$ の実験によれ ば，分布は対数則の下方にシフトする.しかし，傾き は変わらない，後に見る Lee-Sung ${ }^{(10)} の$ DNS でも下方 にシフトする，しかも，傾きが急になる．一方，例え ば Skåre-Krogstad ${ }^{(18)}$ の実験によれば，非常に強い圧力 勾配にも関わらず，通常の対数則が成り立っている. もちろん圧力勾配の強さによるし, DNSでは低レイノ ルズ数の効果もあるかもしれない，また，多くの実験 が通常の対数則が成り立つことを前提にして壁面摩擦 を定めていることに注意しなければならない．本研究 では，対数則が成立するとするデータ (Samuel-Joubert の実験) と成立しないとするデータ (Lee-Sung $の$ DNS) の両方をモデル予測の対象としていることになる.

図 7 にせん断㐫力一枃の分布の流れ方向変化を示 す.ゼ口圧力勾配の境界層では壁面近傍に一定応力層

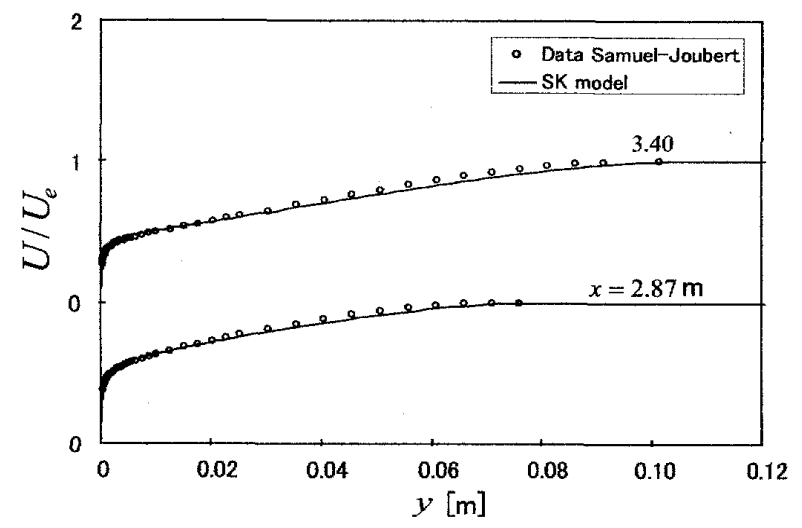

Fig. 5 Mean velocity profiles (Samuel- Joubert flow)

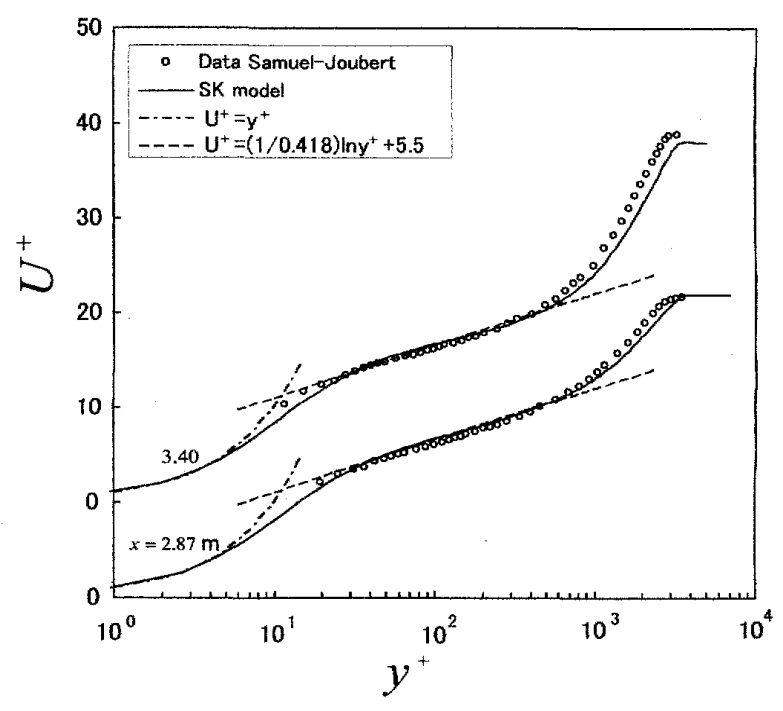

Fig. 6 Mean velocity profiles in wall coordinates (Samuel-Joubert flow)

が存在するのに対し，逆圧力勾配境界層ではせん断応 力は対応する位置で $y$ 方向に正の勾配をもつ，した がって，下流に進むにつれてせん断応力が最大值をと る位置は壁から離れていく，予測は実験データをよく 提えている。

図 $8 \sim 10$ に乱れ強さ分布の変化を示す. $u^{\prime}, v^{\prime}, w^{\prime}$ は それぞれ，流れ方向，壁垂直方向，横方向の乱れ強さ である，下流域の $u^{\prime}$ の分布には，壁のごく近傍におけ る極大のほかに，もう一つの緩やかな極大が現れる。 これは上で茪たせん断応力の極大による応力成分 $\overline{u^{2}}$ の生成によっている. 再分配を受ける $v^{\prime}$ その位置で 最大值をとる. 最下流位置における $v^{\prime}$ が壁近傍で過大 予測されているが, 全体としては予測とデータの一致 は良い。 


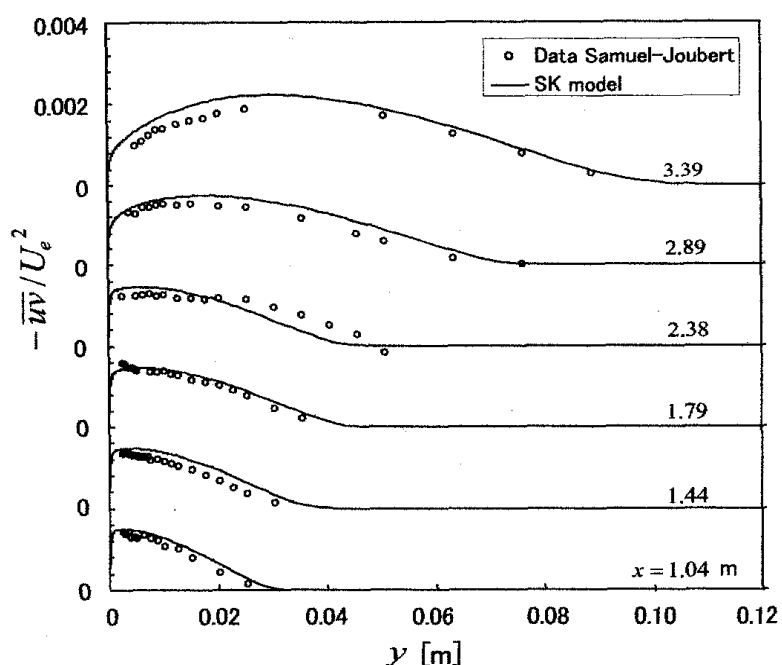

Fig. 7 Shear stress profiles (Samuel-Joubert flow)

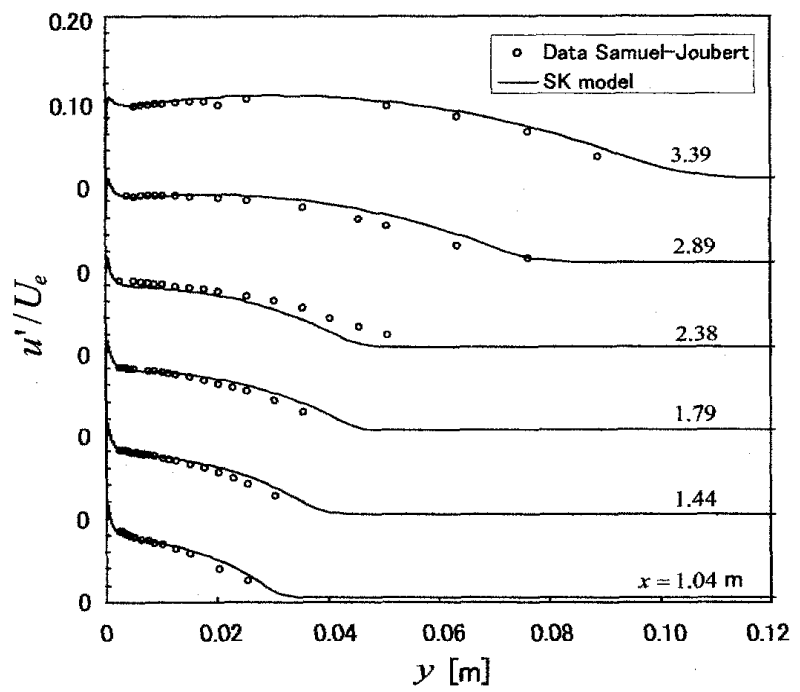

Fig. 8 Profiles of turbulence intensity $u^{\prime}$ (SamuelJoubert flow)

4.2 Lee-Sung ${ }^{(9)}$ の DNS この流れについては, SK モデルに加えて, Launder-Sharma $の k-\varepsilon$ モデルに よる予測結果も示寸，以下では，後者をLS モデルと 呼灾.

図 11 に摩擦係数の流れ方向変化を示す.ここで も摩擦係数は $C_{f}=2 \tau_{w} / \rho U_{0}^{2}$ と定義されている. $x / \theta_{i n} \simeq 900$ では, DNS, モデルともほぼ平衡状態に達 しているのであるが，その位直でモデルは壁面摩擦を 過大予湘している. $m=-0.20$ のタースの $x / \theta_{i n}=900$ における SK モデルの予測值は 34\%過大となっている. SK, LS 両モデルの差は小さい. 流入位置近傍でモデ

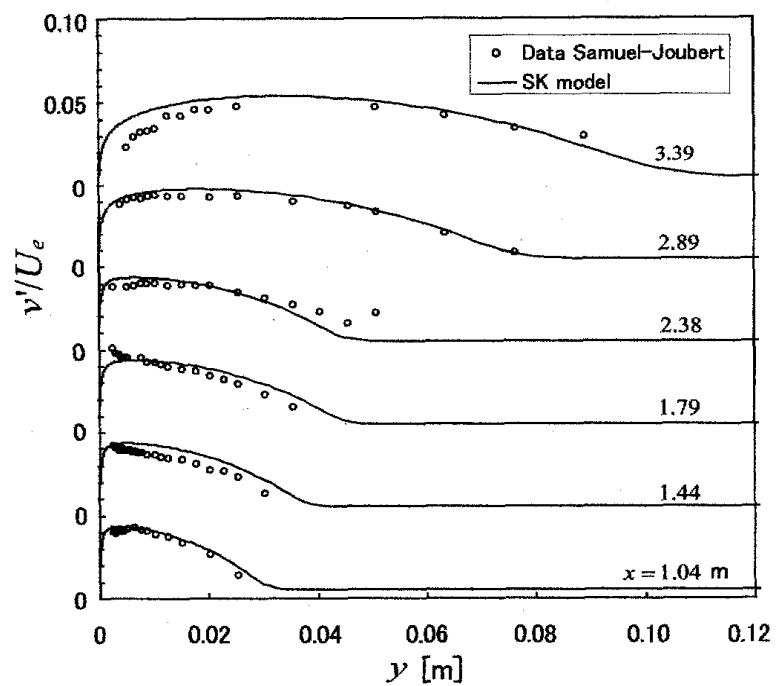

Fig. 9 Profiles of turbulence intensity $v^{\prime}$ (SamuelJoubert flow)

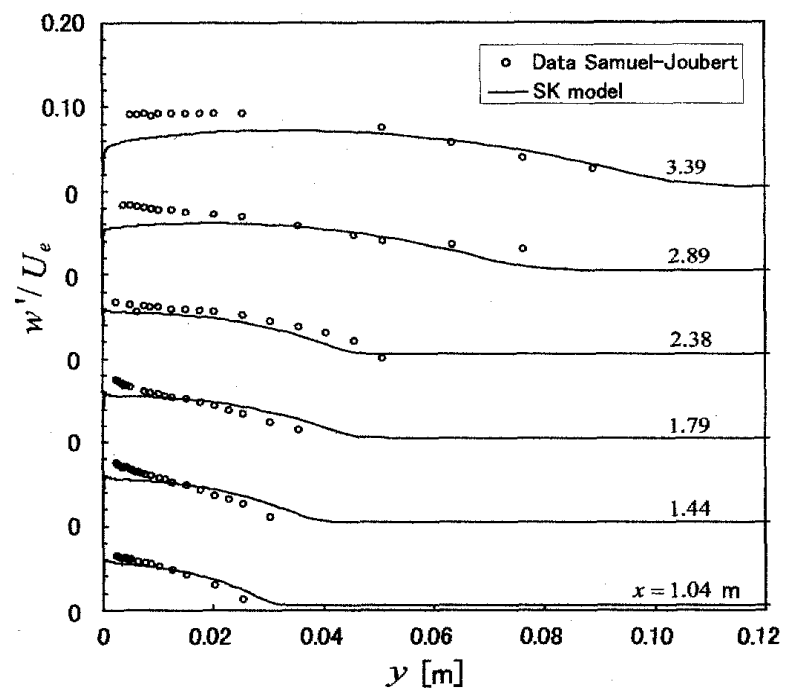

Fig. 10 Profiles of turbulence intensity $w^{\prime}$ (SamuelJoubert flow)

ルは不自然な変化を与えているが，これは流入分布の

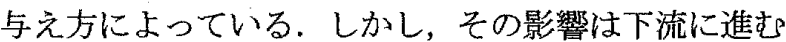
につれて消えていく.

以下では，平衡状態における諸分布について，DNS とモデル予測を比較する. DNSにおいて，その流れ 方向位置は明示されていない。

SK モデルによる $x / \theta_{i n}=900$ における $\left(\beta, R_{\theta}\right)$ の 計算值は $m=-0.075,-0.15,-0.20$ に対して，それぞ れ $(0.25,1270),(0.83,1570),(1.69,1870)$ であり，先 に触れた DNS データと比較すると $\operatorname{Re}_{\theta}$ がかなり高い. 


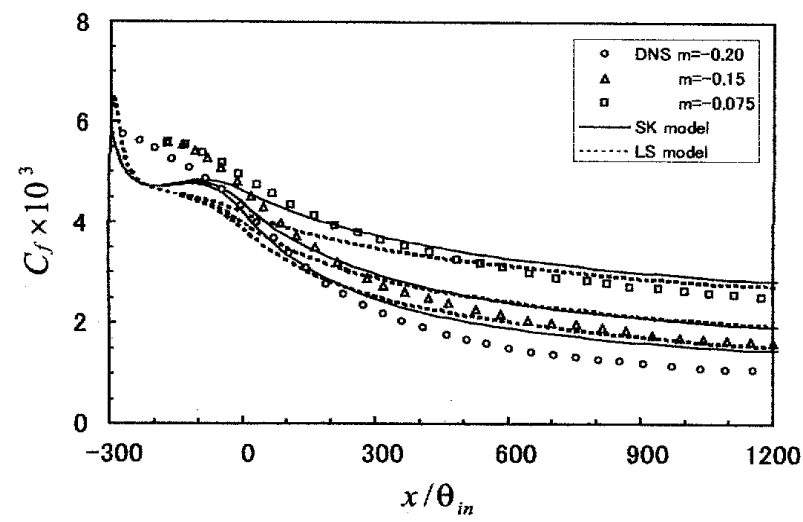

Fig. 11 Skin friction coefficient (Lee-Sung flow)

図 12 に平均速度分布を示す.（a）は壁座標プロッ 卜，(b) 㯈度欠損プロットである. (b) において, $\Delta=$ $\delta^{*} \sqrt{2 / C_{f}^{\prime}}, \quad C_{f}^{\prime}=2 \tau_{w} / \rho U_{e}^{2}$ である. モデル計算の結果 として示したのは $x / \theta_{i n}=900$ における分布である.図 には含まれていないが, $x / \theta_{i n}=1000,1100$ の分布は， 図 12(a)では内層において $x / \theta_{i n}=900$ の分布と重な る.また，図 12(b)ではほぼ全域にわたって 3 位置の 分布は重なる．才なわち，流れは平衡状態にある．壁 座標プロットにおける外層の分布は重ならないが，乙 の差は小さく，以下の議論はそれに影響されない。

図 12(a)においてDNSが示す特徽は，圧力勾配が強 くなるにつれて対数層での分布が対数則から下方へシ フトすることである.しかも，その傾きは急になる。 両モデルとも，下方へのシフトの傾向は捉えているが， 最も強い圧力勾配のケースにおいてはDNS 分布との 相違が目立つ. シフトが大きすぎることよりはむしろ， 傾きが小さすぎることが不一致を生んでいる．分布を $U^{+}=(1 / \kappa) \ln y^{+}+C$ と書くと， $\kappa$ の值は，採用した 標準值 0.418 に対し，DNS では 0.33，SK モデルでは 0.46 である. この場合でも SK モデルは十分な大きさ の伴流成分を与えているように見える．LS モデルの 場合，傾きは SK と較べるとDNSにより近いが，伴 流成分は小さすぎる．全体として見れば，SK モデル は中程度の強さの圧力勾配までは，許容範囲内の予測 を与えると言えよう．LSについても同じことが言え るように見えるが，その問題点を次に指摘する.

Lee-Sung は圧力勾配のない場合についても DNS を行い, その結果を $\operatorname{Re}_{\theta}=1430$ における DeGraaffEaton $^{(19)}$ の実験デー夕と比較している. 本研究におい ても，SK, LS 雨モデルを用いてゼロ圧力勾配境界層を 計算した. 図 13 において，その $\boldsymbol{R e}_{\boldsymbol{\theta}}=1430$ における 速度分布をDNS データと比較する. SK モデルは対数
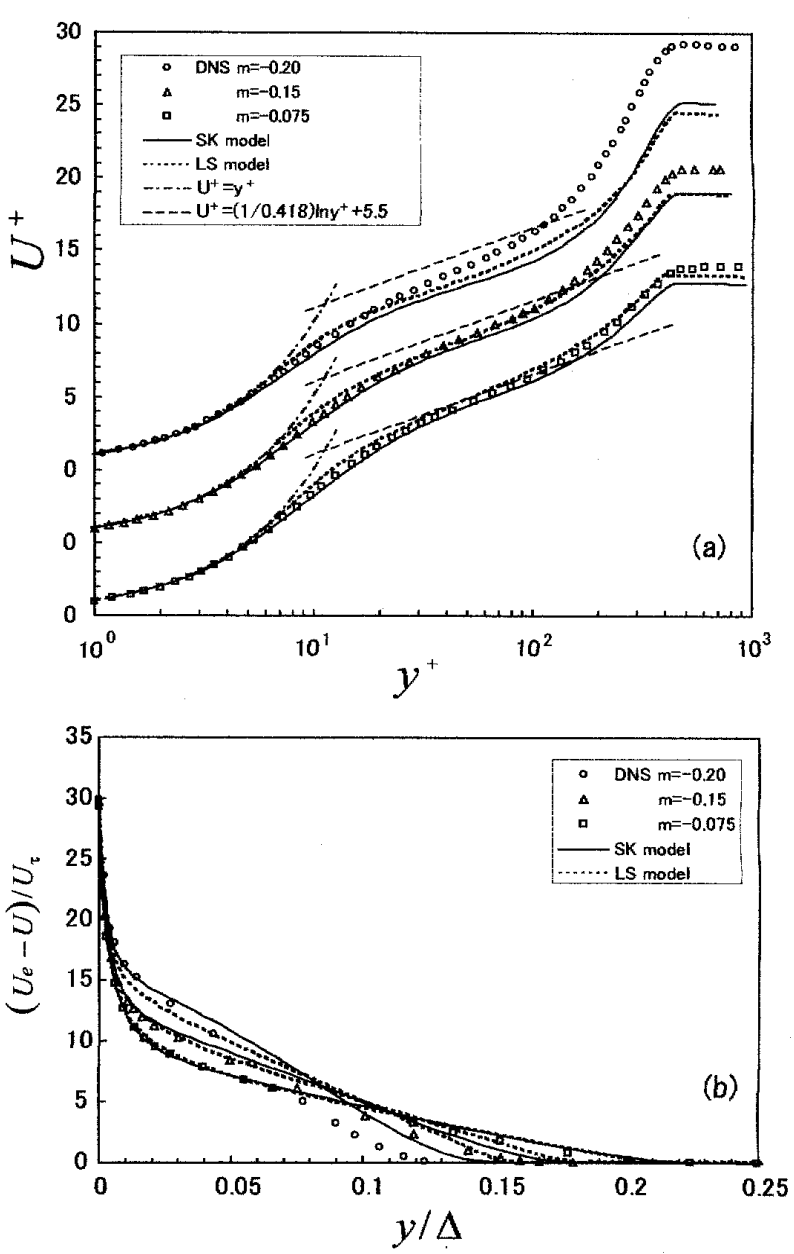

Fig. 12 Mean velocity profiles (Lee-Sung flow),

(a) Velocity profiles in wall coordinates,

(b) Velocity defect profiles

則 $U^{+}=(1 / 0.418) \ln y^{+}+5.5$ を捉えている. DNS 分布 はやや下に位置しているが，その差は小さい. LS モ デルでは分布は対数則の上方に位置し，傾きはやや急 である. 摩擦係数 $C_{f}=2 /\left(U_{e} / U_{\tau}\right)^{2}$ の值は DNS に比 して $12 \%$ 低となっている. 乱流モデルを作る場合，通 常，チャネル流や平板境界層を参照しつつモデル定数 が定められる．SKモデルでも，チャネル流が再現さ れるように定数が決められている．一方，LS モデル では，モデル定数を定めるに際し，チャネル流や平板 境界層が参照されていない.その結果，上述のような 対数則におけるずれが生じている，LS モデルの場合， このことが，逆圧力公配の場合の速度分布と摩擦係数 の予測をデータに近づける方向に効いている.

以下では，乱れに関する諸量を壁座標において検討 する. 圧力勾配のないケースについても，上述の位置 


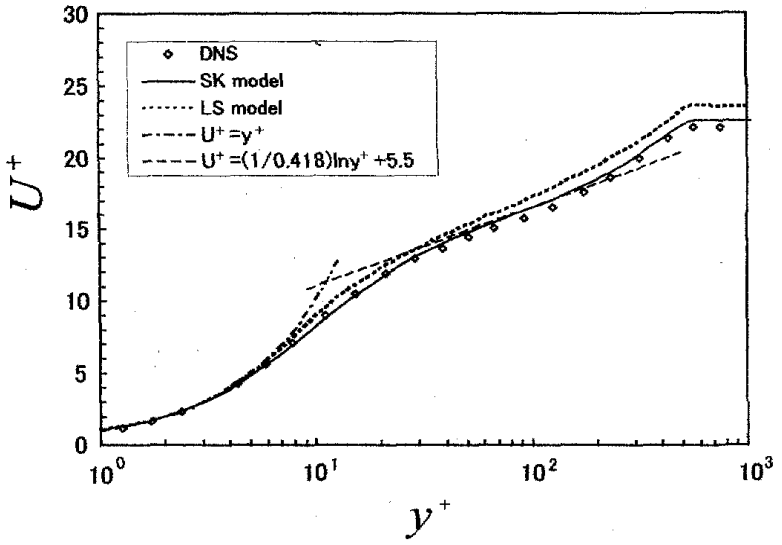

Fig. 13 Mean velocity profile in zero pressure gradient boundary layer

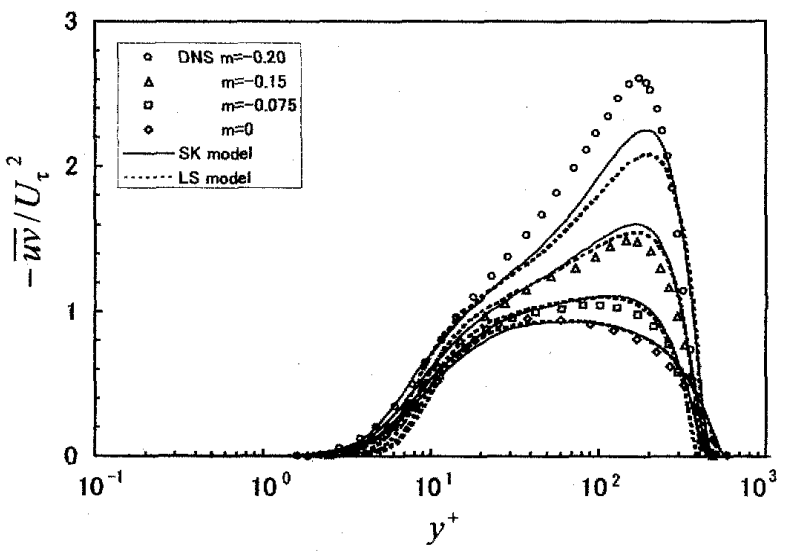

Fig. 14 Shear stress profiles (Lee-Sung flow)

\section{における分布を示す。}

図 14 はせん断応力分布である. Samuel-Joubert の流 れと同じく，粘性影響領域の外端 $\left(y^{+} \simeq 40\right)$ において も，逆圧力勾配によってせん断応力は正の勾配をもっ ている.したがって，ピークをとる位置は外側へシフ トする，庄力勾配が中程度の強さまでは，モデルの予 測はデータに近い。

図 $15,16,17$ に乱れ強さの分布を示す. せん断応力の ピークによって，外層に $u^{\prime}$ の大きい領域が生じる. それ に応じて, $v^{\prime}, w^{\prime}$ はその位置で最大值をとる. $m=-0.20$ では，その位置での $u^{\prime}$ のピークの高さは壁近傍のそ れを超えている. モデルはその傾问を捉えているが定 量的一致は得られていない。

\section{5. 結悥}

Shima-Kobayashi ${ }^{\left({ }^{9}\right)}$ が提案した応力方程式モデルに よって逆死力勾配を伴う乱流境界層の数值予測を行っ た. $\boldsymbol{\varepsilon}$ 輸送モデルには，最も簡単な標準形が用いられ

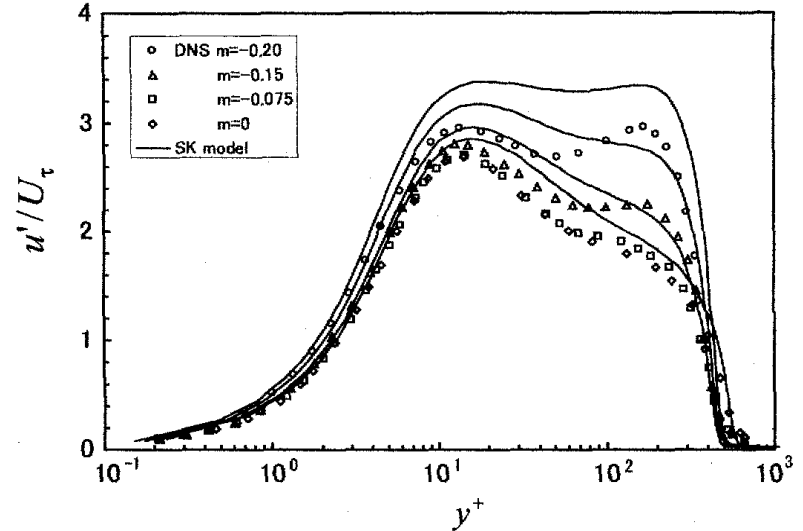

Fig. 15 Profiles of turbulence intensity $u^{\prime}$ (Lee-Sung flow)

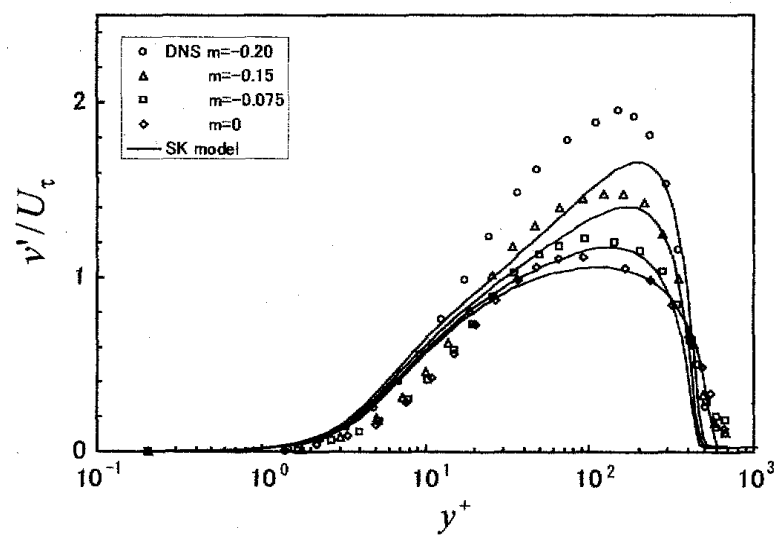

Fig. 16 Profiles of turbulence intensity $v^{\prime}$ (Lee-Sung flow)

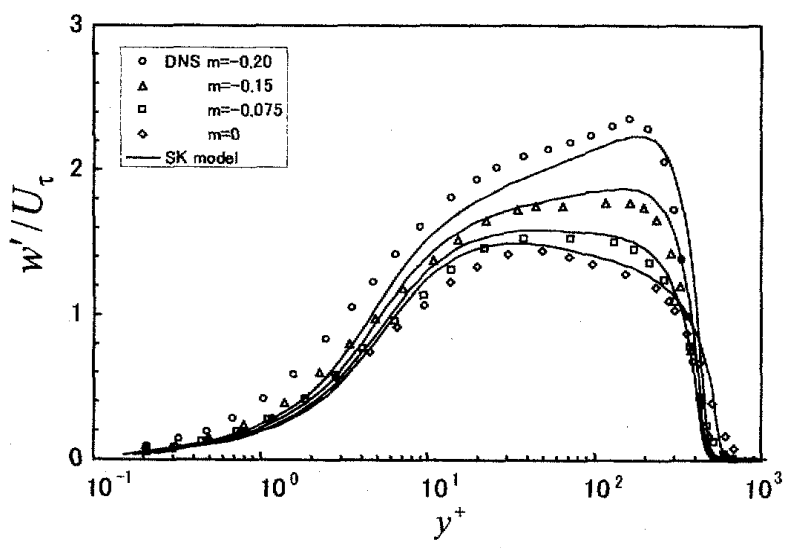

Fig. 17 Profiles of turbulence intensity $w^{\prime}$ (Lee-Sung flow) 
ている.

Samuel-Joubert ${ }^{(4)}$ の流れにおいては通常の対数則に したがう領域が存在する. モデルはその対数則ととも に大きい伴流成分も捉え，低い摩擦係数をよく再現し た.これは, 従来の多くのモデルとは異なり，本モデ ルではこの流れを再現するために $\boldsymbol{\varepsilon}$ 輸送モデルへの付 加項の導入は不要であることを意味している.

Lee-Sung ${ }^{(10)}$ の流れにおいては，対数域における分布 は対数則の下方にシフトする，圧力勾配が弱いケース， 中程度のケースでは，モデルはまずまずの予測を与え た. 圧力勾配が強い場合も，平均速度分布における伴 流成分は十分大きい. しかし, 対数域での分布の傾き はDNSに較べて小さすぎる.

Launder-Sharma ${ }^{(11)}$ モデルは, Lee-Sung の流れにお いて一見，本モデルと同等の予測を与えた.しかし， このモデルは，基本である圧力勾配のないケースにお いて対数速度分布を忠実にとらえない，分布は対数則 の上方に位置し，その傾きは大きすぎる。このことが， 逆圧力勾配境界層における好結果の相当部分圭占めて いる。

いまの忘力方程式モデルの枠組みのなかで, 非常に 強い逆圧力勾配の効果を再現するためには，やはり $\varepsilon$ 輸送方程式への付加項の導人が必要であると考えられ る. 本研究の結果は, 応力再分配モデルの構成しだい で，そのような項の役割を限定的なものにすることが できることを意味している。

\section{文献}

(1) Kline, S. J., Cantwell, B. J. and Lilley, G. M., The 1980-81 AFOSR-HTTM-Stanford Conference on Complex Turbulent Flows, (1981), Stanford University.

(2) Patel, V. C., Rodi, W. and Scheuerer, G., Evaluation of turbulence models for near-wall and low-Reynolds number flows, Third Symposium on Turbulent Shear Flows, (1981), pp.1.1-1.8, University of California.

(3) Patel, V. C., Rodi, W. and Scheuerer, G., Turbulence models for near-wall and low Reynolds number flows: A review, AIAA Journal, Vol.23, No.9(1985), pp.1308-1319.

(4) Samuel, A. E. and Joubert, P. N., A boundary layer developing in an increasingly adverse pressure gradient, Journal of Fluid Mechanics, Vol.66, Part 3(1974), pp.481505

(5) Viti, V., Huang, G. and Bradshaw, P., Numerical study of stress-transport turbulence models: Implementation and validation issues, Computers \& Fluids, Vol.36(2007), pp.1373-1383.

(6) Launder, B. E. and Shima, N., Second-moment closure for the near-wall sublayer: Development and application, AIAA Journal, Vol.27, No.10(1989), pp.1319-1325.

(7) Jakirlić, S. and Hanjalić, K., A new approach to modeling near wall turbulence energy and stress dissipation, Journal of Fluid Mechanics, Vol.459(2002), pp.139-166.

(8) Manceau, R. and Hanjalić, K., Elliptic blending model: a new near-wall Reynolds-stress turbulence closure, Physics of Fluids, Vol.14,No.2(2002), pp.744-754.

(9) Shima, N. and Kobayashi, H., Modelling of the Reynolds stress redistribution with a wall effect vector, Fluid Dynamics Research, Vol.39(2007), pp.320-333.

(10) Lee, J.-H. and Sung, H. J., Effects of an adverse pressure gradient on a turbulent boundary layer, International Journal of Heat and Fluid Flow, Vol.29(2008), pp.568578.

(11) Launder, B. E. and Sharma, B. I., Application of the energy-dissipation model of turbulence to the calculation of flow near a spinning disk, Letters in Heat and Mass Transfer, Vol.1(1974), pp.131-138.

(12) Daly, B. J. and Harlow, F. H., Transport equations in turbulence, Physics of Fluids, Vol.13(1970), pp.26342649.

(13) Leonard, B. P., A stable and accurate convective modelling procedure based on quadratic upstream interpolation, Computer Methods in Applied Mechanics and Engineering, Vol.19(1979), pp.59-98.

(14) Sweby, P. K., High resolution schemes using flux limiter for hyperbolic conservation laws, SIAM Journal on Numerical Analysis, Vol.21, Issue 5(1984), pp.995-1011.

(15) Patankar, S. V., Numerical Heat Transfer and Fluid Flow, (1980), Hemisphere.

(16) Spalart, P. R., Direct simulation of a turbulent boundary layer up to $R_{\theta}=1410$, Journal of Fluid Mechanics, Vol.187(1988), pp.61-98.

(17) Nagano, Y., Tagawa, M. and Tsuji, T., Effects of adverse pressure gradients on mean flows and turbulence statistics in a boundary layer, Turbulent Shear Flows 8 , F. Durst et al. (eds.), (1993), pp.7-21, Springer.

(18) Skåre, P. E. and Krogstad, P. - ^., A turbulent equilibrium boundary layer near separation, Journal of Fluid Mechanics, Vol.272(1994), pp.319-348.

(19) DeGraaff, D. B. and Eaton, J. K., Reynolds-number scaling of the flat-plate turbulent boundary layer, Journal of Fluid Mechanics, Vol.422(2000), pp.319-346. 